\title{
FORMAL AND INFORMAL SUPPORT AT ICE- LANDIC UNIVERSITIES: EXPERIENCES OF STAFF MEMBERS AND IMMIGRANT STUDENTS
}

Due to increased migration in recent decades, universities must adapt their practices to meet the needs of a changing student body. Many immigrant students desire to complete their studies at universities, yet factors such as language of communication and cultural traditions limit their possibilities. This paper comes out of a study titled Educational Aspirations, Opportunities and Challenges for Immigrants in University Education in Iceland. The findings are based on individual interviews with immigrant students and university staff members and focus group interviews with immigrant students. The theoretical framework of the study draws from the ideas of culturally competent counselling. This helps to analyse immigrant students' experiences of formal and informal support during their university studies (Arredondo et al., 1996; Maunonen-Eskelinen, Kaikkonen \& Clayton, 2005). Formal support constitutes institutional support provided by the universities, such as orientation programs and social activities of various kinds. Informal support, in contrast, incorporates other means of assistance to immigrant students either through those whom they trust, such as instructors, or community members in the role of cultural brokers. Immigrant students also get support through their present and former friends and through their extended family members. The findings indicate that, despite the challenges that immigrant students face at Icelandic universities, the majority were quite positive about their experiences as they described different types of formal and informal support which they obtained throughout their studies.

Keywords: immigrant students, higher education, formal \& informal support, inclusive environment, Iceland

\section{INTRODUCTION}

The languages, cultures and religions of Iceland's population have become increasingly diverse in the past years. The proportion of immigrants out of the total population was $1.8 \%$ in 1995, 2.6\% in 2000 and 3.6\% in 2005 (Statistics Iceland, 2017). According to Statistics Iceland, the percentage of residents with foreign backgrounds, including first and 
second generation immigrants, was 20.8\% in 2018 (Statistics Iceland, 2018b). Student populations at all levels of education reflect this development (Statistics Iceland, 2018c, $2018 d, 2018$ e). In the fall of 2017, students of foreign origin comprised about $19 \%$ of all newly registered university students at all university levels (Statistics Iceland, 2018a).

Increased mobility around the world brings new opportunities and challenges to educational settings at all levels. Educational institutions are working to acknowledge immigrant students' diverse needs and provide academic and social support during the learning process. While this awareness has increased significantly at the level of compulsory education, higher education institutions lag behind in their understanding of the needs of immigrant students (Boesch, 2014). The European Higher Education Area (EHEA) in 2015: Bologna Process Implementation Report reveals that foreign-born students in the majority of European countries are early school leavers and less likely to participate in tertiary education. The report includes the youth population aged 18 to 29 . The participation gap between native born and foreign born in Iceland, Norway, Finland and Sweden, in particular, is between four and eight percentage points (European Commission/ EACEA/Eurydice, 2015). Various other studies show that immigrant students experience different challenges during the education process, such as language related issues, lack of social support and insufficient knowledge about local educational systems (Franke, 2015; Ragnarsdóttir \& Blöndal 2007; Sinacore \& Lerner 2013).

Studies have shown that higher education institutions can play positive roles in alleviating these challenges by providing different types of institutional support. However, some of the students either prefer to be supported by their peers, friends or other community members, or they are unfamiliar with the quality and quantity of formal support offered to students.

The purpose of this study is to explore different types of support and the challenges immigrant students experience during their undergraduate studies at three Icelandic universities. Furthermore, the study explores university staff members' perspectives on the different services they provide. The study also adds to the research literature on universities and informs them about the different types of support that may be useful for disadvantaged groups.

\section{THEORETICAL BACKGROUND}

This study is based on the theoretical foundations of critical multiculturalism, a field that mainly focuses on the cultural rights of minorities, including their right to education (Parekh, 2006). In his work, Parekh (2006) notes that modern cultures are increasingly pluralistic. For this reason, societal domains such as education should explore ways to increase equality for all. Entailed in this endeavour, according to Giroux (1993) and Banks (2016), is the challenge of understanding and acknowledging the increasing diversity of society and developing measures to counteract inequalities and other types of marginalization. 


\section{Culturally competent counselling}

Immigrant students' experiences of formal and informal support during their university studies can be used as a point of departure through the concept of culturally competent counselling. Arredondo et al. (1996) and Maunonen-Eskelinen et al. (2005) claim that there is a need for culturally appropriate and multi-faceted support and guidance for immigrant students that targets their knowledge, views, skills, and goals within the university learning space. Studies have reported that understanding the distinct and common educational and social contexts of these students assists in developing appropriate strategies to support and engage them (Gloria \& Rodriguez, 2000; Hertzberg, 2017; Maunonen-Eskelinen et al., 2005; Swaminathan \& Alfred, 2001). Systematically, the lack of relevant institutional support can lead to unfavourable outcomes for students with various backgrounds, impairing the success of their studies (Engstrom \& Tinto, 2008). This accentuates the critical role of tertiary institutions in accommodating the needs of their diverse student groups.

In addition to culturally competent counselling, cultural proficiency captures how democratic institutions challenge individuals, and organizations look more closely into the dominant culture and its impact on others. Cultural proficiency views diversity as a valuable resource focussing on knowledgeable and respectful interactions among a variety of cultural groups (Lindsey, Roberts, \& Campbell Jones, 2005). In the field of education, cultural proficiency is known as the knowledge-based skills and understandings necessary to successfully teach and interact with students from a variety of cultures. It is seen as a lifelong learning process that includes acknowledging differences, adopting new tools, and adapting to different learning styles (Lindsey et al., 2005). In other words, the terms culturally competent counselling and culturally competent proficiency refer to the ability of educators and counsellors to successfully serve students from various racial, linguistic, ethnic, or economic groups. Lindsey et al. (2005) view cultural proficiency as a more advanced state of cultural competence in which educators believe that diversity adds positive value to the educational enterprise.

Gray, Rolph, and Melamid (1996) and Owens and Lynch (2012) state that minority university students, or those with foreign backgrounds, generally show more resilience and perseverance in pursuing their studies than their peers. They claim that this is because these students tend to face more educational and social hindrances related to their circumstances that are commonly not addressed at universities. Maunonen-Eskelinen et al. (2005) claim that the studies of non-native speakers are often interwoven with the added task of learning their field in their weaker language. Jehangir (2010) points out that those with a foreign background are mostly of low socioeconomic status, in low-paying employment, and, in many instances, serve as the primary caretakers of their families during their studies. Consequently, these students usually have low graduation rates from universities (Engle \& Tinto, 2008). Despite all the hurdles, these are students who continue to aspire for and pursue their university studies in the hope of increasing their opportunities for employability, security, and membership in their new society (Jehangir, 2010). Robertson (2010) argues that access to higher education and university completion gives students better opportunities in the labour market and empowers them. 
Sinacore and Lerner (2013) studied the cultural and educational transitions of first-generation immigrant students in Quebec, Canada. Their findings reveal that undergraduate immigrant students are challenged with various societal and psychosocial barriers on their way to academic success and social integration, including a language barrier and lack of social support. Moreover, their study showed that immigrant students faced institutional barriers, such as inadequate knowledge about Canada's educational system, unresponsiveness of university staff, and difficulty in academic credit transfer, which resulted in challenges to transitioning into university. Their study also showed that career services were among the few places where students could seek support, ranging from basic living, language, and legal matters, to navigating the university system.

\section{Formal support}

The term formal support is applied to institutional support that happens inside the educational institution. It is structured, organized and administered according to a given set of laws and norms. It includes a variety of specialized programmes and professional support, such as from educational counsellors, international offices, and other organizations inside the university. Social or informal support relates to the individual student and resources in his or her physical and social surroundings, whether from work, the library, mass media, family, friends, or neighbours. This type of support takes place without any program; it is unstructured and depends on the daily needs of the individual student. It normally takes place both within and outside of educational institutions. According to Bossu, Brown, and Warren (2018), formal support is expert-oriented. It refers to the direct role of faculty and university staff in the delivery of the university programs, teaching, leading, facilitating, and instructing.

A study of teacher education programs in universities in Iceland reveals marginalization and exclusion of immigrant students from group activities (Ragnarsdóttir \& Blöndal, 2007). Furthermore, recent research on immigrant students in an international program in education studies at the University of Iceland shows that diverse teaching methods for diverse student groups are empowering and play an important role in creating a positive learning environment for international students (Ragnarsdóttir \& Blöndal, 2014). A pioneer in social constructivist theory, Vygotsky, as is introduced in Snowman \& Biehler, (2006), referred to the fact that well-designed instruction is like a magnet and that there is a difference between what a person can do on his own and what he or she can accomplish with some support. Structuring appropriate support for immigrant students through peers, teachers, or institutions both inside and outside universities can enhance successful completion of their studies.

\section{Social support}

Earlier studies emphasise the fact that social support from peers could be as important as the formal backing provided by universities (e.g., Dennis, Phinney, \& Chuateco, 2005; Inkpen \& Tsang, 2005). Inkpen and Tsang (2005) consider networking to be an umbrella concept for social support. Mead, Hilton, and Curtis (2001) define peer support as a system of reciprocity based on principles of respect, shared responsibility, and mutual 
understanding of what is helpful. This is about finding affiliation with others and feeling a connection. According to an analysis by Dennis et al. (2005), peer support from other university students, or the lack thereof, has the strongest correlation with academic progress. The participants also reported that peer support was the most helpful strategy for dealing with academic barriers. In line with Dennis' et al. (2006) analysis, other studies have shown that immigrant students' success increases through implementing programmes, counselling, and peer-support initiatives designed for different student profiles and circumstances (Crisp \& Cruz, 2009; Engle \& Tinto 2008; Wilson \& Arendale, 2011). Immigrant students at universities may better be able to overcome hindrances in their studies with both formal or expert-oriented assistance and informal, peer-oriented activities (Maunonen-Eskelinen et al., 2005).

The above-mentioned research and theories emphasize the importance of both formal and informal support for immigrant students at tertiary level. The type of support students seek and receive inside educational institutions is referred to as formal support. On the other hand, informal or social support refers to the external resources accessed outside universities.

\section{METHODS}

Data for this study were originally collected as part of a larger research project to examine the educational aspirations, opportunities and challenges of immigrant students at universities in Iceland. The interviews were conducted from September 2016 until April 2018. The participants in the study were first-generation immigrants living in Iceland. The main condition for participation was that the participants had studied at undergraduate level for at least one year at the University of Iceland, the University of Akureyri or Reykjavík University. An additional condition was that the participants were not exchange students. The research focuses on first-generation immigrants because they are a relatively large group within the universities and, according to previous studies (e.g., Ragnarsdóttir \& Blöndal, 2007, 2014), they experience various challenges during the educational process, such as language-related issues and obstacles to accessing support services. Furthermore, the percentage of second-generation immigrants is still low in Iceland (Statistics Iceland, 2018b). It is more difficult to identify second-generation students in Icelandic universities as the majority of them hold Icelandic citizenship and are registered accordingly.

Despite the awareness of diversification among the student population and universities' responsibilities in reaching out to immigrant students, little information is available in the three universities referred to as to how they are addressing student diversity (Wozniczka \& Ragnarsdóttir, 2016). In order to obtain rich data, 41 immigrant students were recruited through maximal variation sampling (Flick, 2009) based on gender, age, place of origin, socio-economic status (SES), number of years in Iceland, field of study, and proficiency in their mother tongue, Icelandic, and English. 


\section{Data collection and analysis}

A qualitative research design was used to explore the nature of support and challenges faced by immigrant students in universities in Iceland. Initially, the registrars of the universities were asked to provide information about immigrant students currently enrolled in different undergraduate programmes.

Two qualitative research methods were used for collecting data, individual in-depth interviews and focus groups. Data collection started with focus group interviews with three to five participants in each group for a total of seven groups. The aim of the focus group interviews was to generate topics for semi-structured, in-depth interviews with individual students. The main advantage of focus groups is the opportunity to observe a large amount of interaction on a topic in a limited period of time, based on the researcher's ability to assemble and direct the focus group sessions (Lichtman, 2013).

Individual semi-structured, in-depth interviews were conducted with the same participants to elicit their views as clearly and accurately as possible (Brinkmann \& Kvale, 2015; Flick, 2009). Twenty-nine students from the University of Iceland, nine students from the University of Akureyri and three students from Reykjavík University participated in the study. There were 12,296 students enrolled in the University of Iceland, 2,074 in the University of Akureyri and 3,800 enrolled in Reykjavík University during the academic year 2017-2018.

Additionally, individual in-depth interviews were conducted with 16 university staff members, such as student and career counsellors, international office administrators, service desk staff, teachers, and other staff members providing services to immigrant students at the three universities. Ten of the staff members were from the University of Iceland, three of them were from the University of Akureyri and three from Reykjavík University.

Both students and staff members provided information on structures and formal support within the universities. Participants were also asked about their experiences of formal educational support within their institutions, the specific educational support they need, and the kind of assistance they receive through their social networks.

The interviews were conducted in Icelandic and/or English. Data analysis was simultaneous with collection throughout the research process. The data gathered were transcribed, analysed, coded, and interpreted (Creswell, 2008). Thematic analysis was applied to identify, analyse, and report patterns within the data (Braun \& Clarke, 2013). The analytical software Atlas.ti, which is proven to be useful for analysing vast amounts of qualitative data, was used to code the interviews and generate the themes related to the research topics (Paulus \& Lester, 2016).

All privacy considerations were in compliance with the Icelandic Act No.77/2000 on data protection. The participants' identities were kept secret and their contact information was never shared. All participants signed the consent forms and they were informed that they could skip answering any questions or terminate their participation at any time without explanation. 


\section{Contextual information}

The paper explores immigrant students' experiences of formal and social support in Icelandic universities. Different types of services are offered by the universities in Iceland. These include the structure and organization of studies from the school or faculty offices, services of evaluating previous studies outside Iceland; in addition, other certificates such as rental subsidies, maternity leave, or leaves of absence are supplied by the registrar. The international office manages, develops, and administers international affairs for international students, along with participation in international networks and cooperation with academic partners. Other services, for example advice on courses, programme selection, working methods, and resources for students with special needs are offered by student counselling and career centres. Various types of support around technical and IT issues such as wireless network, connection to Eduroam, e-mail and calendar, printing and scanning and free software are provided by the university computing services. The student council handles issues students have within university, safeguards their interests and listens to their voices, both within the university and in the outside community, by publishing a student newspaper, organizing social activities, and attending to issues related to students' interests, equality and rights. University writing centres offer tutoring on all types of written assignments for students at both undergraduate and postgraduate levels. University libraries also offer students an introduction to academic databases and instruction on finding sources (Reykjavík University, n.d.; University of Akureyri, n.d.; University of Iceland, n.d.-a).

\section{FINDINGS}

Immigrant students at the universities under study in Iceland are a very diverse group, and they face a number of challenges depending on their circumstances upon arrival in Iceland. However, many of these students manage to navigate their way through different types of support inside and outside universities. This section presents different ways that immigrant students obtain support, such as from teachers, counsellors, writing centres, registrars, mentors, peers, employers, etc. The study also revealed that immigrant students sometimes get support from friends outside the university and from other community members. The main findings are grouped into two different types of assistance: formal support from the institutional domain and informal support students sought from their social domains.

\section{Formal support from the institutional domain}

The universities under study offer various types of services for both international and domestic students. Sources of formal support include student counselling and career centres, international offices, service desks, writing centres, and campus services. The participants in this study reported the use of these services but encountered language and cultural difficulties that deterred them from benefiting from them. During the interviews, the students were asked to share their experiences regarding these support services and to describe the reasons why they had to seek help. 


\section{Students' experiences of formal support services}

The most frequently used support facility described by the participants was the service desk, where students received different documents and were helped to resolve practical issues, such as how to apply for study, which documents they needed for the application, how to connect to the school internet, how to register for courses, how to use intranet, etc. Additionally, the service desks provide information on further support services and staff members to contact in order to resolve issues which are outside the service desk's scope. A great majority of participants were satisfied with the service desks and made positive comments regarding the services provided and the staff members:

When I asked for anything that was administrative, the answer was always super accurate, superfast ... especially like, let's say, you just go to the main student like when you need your card, your student card, and you need a lot of papers because of my immigration paper every six months ... it was always super friendly and effective and everything. (Participant who studied Icelandic and English)

Participants' experiences of communication with the student counselling and career centres varied. Many participants said they were unfamiliar with the services provided by the student counselling and career centres and where they were located. Some participants had heard about the centres but had never contacted them because they did not feel the need. Several participants had contacted the centre, and their experiences varied considerably:

In the beginning, it was for choosing courses, like what should I choose and what should I do and so on. But now, I mostly talk with them about how to finish my bachelor's degree. The woman called ***, I just remembered her name, she actually helped me a lot. (Participant A who studied social sciences)

*** Name of the staff member at student counselling and career centre

One of the participants talked about two visits to a counselling centre where he met different counsellors on each occasion and experienced very disparate levels of service. There might be two reasons for the different services, in his opinion. One of them was that different counsellors had divergent attitudes towards him. The other reason was that he came better prepared for the second visit. He had checked the information about the studies beforehand and had formulated specific questions:

When I was applying to university, I also have mixed experience with the student counselling because the first time I went to ask basic questions ... I got these really straight answers, "Oh it's online. Oh you can check it there. Oh it's this and that", so basically it felt like okay, so I'm just wasting your and my time here because, there was no clear explanation ... It was like an information desk. But then the push from my parents, like okay you go and ask more questions. So, I organized a little better, checked out more things I want to do and then luckily another woman took me, she was very friendly ... and it felt like I was actually welcome there. So, I guess it also depends on who you are going to talk to, because it's two different cases, or two similar cases, but different answers. (Participant who studied Chinese) 
As for the students who were not aware of the assistance provided by academic counsellors, they particularly benefited from the encouragement of peers who helped them seek the necessary assistance:

[Translation from Icelandic] Yes, I got help once, an important aid for me when I couldn't pass the exam, and I had to go home. My friend, he just, we went to the university, [and he said] maybe they can help you. I was like "no, no, no." I don't understand how they could help me, and he just took me, and we went to a woman on the second floor. Yes, she called the Directorate of Immigration for me. I was very surprised because I didn't understand why she was doing this. This was my problem, not [hers]. I did not expect that this would help, but she waited very long and when they got the response from the Directorate of Immigration, and they gave me a lot of explanation, talk talk talk, and then [they said] yes, you can [stay and] study more, and I was shocked. This worked. Yes, I hope that people, someone who has a similar problem. I just tell you go to her and get help. It doesn't really work all the time, yeah, but maybe I was just lucky. I don't know. (Participant who studied Icelandic and foreign languages)

The international office offers a variety of services for university students, such as assistance with applications for student exchange programmes and supervision of a mentor system, a support service available to all students with a foreign background. Two of the international office's main tasks are to assist exchange students and communicate with foreign universities. Several participants reported mixed experiences with the international office at their institutions. For instance, when they sought help as immigrant students, staff at one international office replied that they only assisted students who would like to study abroad:

Honestly, I haven't found it, somebody, when you go to the international students' office, they said: "Oh, no we are for people who go to study abroad, not for people who are here." Then I just went: "Oh, I didn't know that." (Participant A who studied educational sciences)

However, when the participants needed information regarding student exchange programmes, their experiences of communicating with the international office were highly positive:

I like Alpjóđaskrifstofa [International Office] yeah. When I went Erasmus ... They helped me a lot. So, if I had some questions, they were always there to help me, and if I write there mostly to $* * *$, she always replies immediately. (Participant who studied international affairs)

*** Name of the staff member at the international office.

A mentor programme was introduced in the University of Iceland by the international office several years ago. "The main task of the mentor is to provide the student with practical information about the University of Iceland and Icelandic society, as well as introducing him/her to the students and student life in general" (University of Iceland, n.d.-b). Even though the intentions of the mentor programme can be seen as highly positive, the participants who attempted to apply for a mentor mainly reported negative experiences. One of the participants explained that he felt like this programme was primarily designed for exchange students and not for domestic students of foreign origin. During one of the 
interviews, the participant who studied Icelandic language and educational sciences discussed the mentor program:

Student: There is a mentorship program, it doesn't work! It doesn't work. It's not effective at all ... like $100 \%$ I'm sure about it.

Researcher: Yeah, have you experienced it? The mentor...

Student: No one knows about it.

Researcher: Oh, is that the problem?

Student: Erasmus knows, but there are so many students that are not in Erasmus and $80 \%$ are not in Erasmus, if not more. So, it's basically not-present at university.

As demonstrated in these findings, there was lack of information regarding the mentor programme. The participant learned about the possibility of getting a mentor when it was too late for him. He explained further in his individual interview that if he had known about this programme beforehand, it could have been a big help for him.

In terms of academic assistance, participants sought help from teachers, who usually were open and willing to assist:

I really relied on some of my favourite teachers for these courses. I can think of two particularly who got a lot of emails. I talked with my thesis advisor, and I did not, I tried, sort of, the head of the program, and the, the emails back and forth between, that person and the person who coordinated the graduation they just kept telling me to ask someone else because that was not their field. (Participant who studied Icelandic and educational sciences)

Furthermore, participants generally underscored the importance of the academic services provided by the university library and, more specifically, the writing centre, where students could receive help with writing their assignments and theses both in Icelandic and English. One participant expressed her gratitude for the writing centre and said that they helped her to improve her skills in academic writing. She had previously studied in other countries, but she had not received writing support anywhere except in Iceland:

For me, it was also quite challenging, like in the beginning. It's still challenging, but I was so happy to have ${ }^{* * *}$. We have this fantastic woman that you can come and consult about any of your writing and it's amazing. It's such a help, I think, that we have, like, such person who can go through everything and help how we can improve. So yeah, I think that I didn't have anywhere else ... support. I think yes this is very, so important you know. (Participant B who studied educational sciences)

*** Name of the staff member at the writing centre

As a whole, the support provided by the institutional domain at all the universities under study tended to be in accord with the students' expectations, intentions, and efforts of seeking information and assistance. The invisibility of some of the support offered and the participants' personal feelings about the support offered by the universities varied.

When the interviews with immigrant students were completed, the researchers interviewed university staff members in order to analyse their perspectives on communication with immigrant students and to gain a deeper understanding of the support services 
they provide. The results of the interviews with staff members are presented in the next section.

\section{Staff members' perspectives on formal support services}

The main themes that emerged from the interviews with staff members were formal support provided to immigrant students, staff members' experiences of communication with immigrant students, and their perspectives on how universities could improve formal support services. Staff members' attitudes toward immigrant students were predominantly positive. Some of them were empathetic; they well understood the realities and difficulties that immigrant students go through when they pursue studies in a new country. Some of the staff members mentioned that immigrant students come to them when they encounter serious problems and are even considering quitting their studies. The majority of the staff members who participated in the research study show a willingness to assist immigrant students, look for possible solutions, and encourage the students to continue their studies:

[Translation from Icelandic] Look, I feel like, for instance, foreigners are more persistent than Icelanders, and they are usually more diligent, you know, in finishing because they are determined to go through their studies. They are just usually more willing to finish ... I always try to tell people and encourage them to continue. It usually works. I tell them not to quit right away, just continue and wait a bit. Usually people do manage to finish, but I understand that it could be difficult because you speak another language, maybe you don't speak very good Icelandic, but if you keep up the effort you may succeed. (Administrative officer)

Staff members from different offices and teachers reported that they are willing to speak English or Icelandic with immigrant students and that language choice does not affect the quality of support provided. The immigrant students who participated in the study confirmed that, in most cases, they can freely choose the language of communication and that university staff members are usually open to speaking English with students with limited Icelandic skills:

[Translation from Icelandic] It doesn't matter to me whether you speak Icelandic or English ... I think it is more important that people have the opportunity and resources to express themselves ... to first give them the opportunity to express themselves and then proceed to do something. (Student counsellor A)

Academic counsellors who participated in the study shared their observations regarding immigrant students' access to formal support services within the universities. They admitted that the majority of services, including extra support courses on topics such as exam anxiety are provided in Icelandic. However, they stated that they would be willing to offer the courses in English if immigrant students showed interest in them. On the other hand, they noted that immigrant students are less likely to come to the student counselling office and ask for assistance and are even less likely to show interest in the courses hosted by the office. 
Additionally, the academic counsellors and the staff at the international offices revealed that those students who come from countries outside of the EU/EEA often ask for assistance in resolving issues regarding student residence permits issued by The Directorate of Immigration. The majority of the interviewed students who come from countries outside the EU/EEA clearly stated that they wished they could receive more assistance in applying for student residence permits. The position of the staff members regarding this matter varied significantly between the universities. Academic counsellors at the University of Iceland stated that they do not have the required qualifications to provide assistance regarding residence permits. They advise students to contact The Directorate of Immigration directly for any issues concerning residence permits:

[Translation from Icelandic] My opinion is that we are basically not working for the Directorate of Immigration, or we are generally here to, first and foremost, introduce and advise people how to gather information about studying at the University of Iceland ... I can't take responsibility for giving them information about something that I ultimately am not a specialist in. We need to approach this carefully so as to not give the wrong information. (Student counsellor B)

Even though the position of the academic counsellor is not to assist students in matters regarding residence permits, the interviews with the immigrant students showed that in some cases staff members do make exceptions and help in extraordinary situations (see an example presented in the previous section).

At Reykjavík University, which is much smaller than the University of Iceland, the international office provides personal support to those students who are obliged to apply for student residence permits. The University is able to offer this kind of support because very few students come from countries outside of the EU/EEA to study there:

I also offer assistance with applying for visas for students from outside the EU. I've created, like, a guide of how to apply for a student visa, so I ask students to read that carefully ... and I have a contact with immigration who I send all the names of the students, and if I'm having issues, I contact them too ... because we usually only have a handful of students that arrive from outside the EU, exchange students, and I've driven them to the immigration department to have their pictures taken. (Staff member)

The international offices in the three target universities offer a range of different activities for both domestic and international new students, including orientation days, campus tours, pub-quizzes, etc. Some of the activities are specifically oriented towards international exchange students, such as a crash-course in Icelandic and the mentor programme discussed earlier. According to a staff member from one international office, the mentor programme was originally designed for exchange students. However, any student with a foreign background can apply for a mentor. Due to these changes, the demand for mentors has been growing very fast, and the international office has difficulties assigning mentors to all of the students who have applied: 
[Translation from Icelandic] Basically, exchange students could, but now only those who are foreign full-time students, they could also apply for mentors ... There were a lot of foreign students who applied. It was surprising to us how many students, foreign ones, wanted mentors. Yes, we did not expect this here, and we had not envisaged that a considerable number would send an application, and that really surprised us. (International office staff member)

To summarise, various types of services for all students are provided by the Icelandic institutions of higher education participating in this study. Due to increasing diversity in the student population, university staff are confronted with the challenge of understanding these changing demographics and are attempting to develop services to address the students' various needs. While some of the students depended on the institutional support offered by the universities, many of them were more dependent on their social networks, like fellow students or support from both close and extended family members.

\section{Informal support for students from the social domain}

In this paper, the term informal support from the social domain is applied to the types of support that students obtain through their contacts and networks, both inside and outside the universities. This includes peer support and assistance through their friends, family members, and acquaintances.

The universities try to promote social interaction between students by arranging activities outside learning hours. Several study participants mentioned a social event called Café Lingua, regularly hosted by the School of Humanities at the University of Iceland. Those participants who attended Café Lingua appreciated the opportunity to meet peers and practise spoken language skills. They wished that Café Lingua could be arranged more often:

[Translation from Icelandic] Now, they have started to organize Café Lingua which was not offered before. I find it enjoyable, now that events like that provide the possibility to practice [the language]. However, Café Lingua is only held once or twice per semester ... It is not enough. (Participant who studied Icelandic and educational sciences)

Getting to know people within the university and expanding their social networks was considered very important by the majority of the participants. Good relations with peers had a positive impact on students' academic performance as this triggered collaborative learning inside and outside the classroom:

The biggest help is my friends. Sometimes, I don't even know I have an essay that we have to deliver next week because I don't understand what is written in the mail, but they always remind me: "We just want to remind you we have an essay." It happened once that we had five essays in one week, but I didn't know it. (Participant A who studied social sciences)

Social contacts outside the university also play an important role in immigrant students' integration and studies. Several participants noted that they received help from their Icelandic friends in the form of proofreading and editing their written assignments in Icelandic: 
[Translation from Icelandic] There are very few [students with a foreign background] who make it to the university, after all, because of Icelandic. This is mostly because of projects. You know, you need to write proficiently in Icelandic and our [mastery] of declensions is, for instance, not as good. You know, I always have to ask someone else to proofread like twice just so, you know, to make sure that I could submit, you know, a good project and things like that. That is extremely hard. (Participant who studied business administration)

Support from family members could also be a key factor in immigrant students' education process. A participant who quit her studies after approximately one year at the university shared her story in one of the interviews. Because the majority of her family members lived in her country of origin, she had to work full-time to support herself while studying at the university. She revealed that her husband was not supportive during that time and that this was one of the main reasons why she decided to quit:

[Translation from Icelandic] That's exactly the reason why. I had to work 100\% and indeed work ... Money was more of a priority for me than school. But as of now, I actually want to go back to school. I want to, and then, I will cut down on my work and maybe get support from my husband, which I didn't get before. (Participant B who studied social sciences)

Some participants mentioned other support services outside the university that had helped them during the education process. One participant shared her positive experience of the Red Cross:

I was very fortunate because I got this support from the Red Cross. The person was also at the university, and every problem that I had at the university, I just told her, and she helped me with them. They had volunteers who just help people, immigrants and asylum seekers, to get to know the society, and I asked them whether they had someone in the university because I had some problems. They introduced someone to me, and we became friends. (Participant who studied Icelandic and dentistry)

The findings ultimately indicate that immigrant students pursuing higher education in universities in Iceland sought different types of support both from the institutions and personal networks. For many of these students, formal or institutional support comes from academic counsellors, international offices, writing centres, teachers, department offices and service desks. Meanwhile, informal support is connected to peers inside and outside university, friends, community-based services, and relatives. The former provided assistance centred on academic matters while the latter provided a set of resources that enabled them to manage psychosocial issues such as stress and crises during their time at university. In the next section, the key findings are discussed in relation to the theoretical framework. The aim is to explore issues of support concerning immigrant students in higher education.

\section{DISCUSSION AND IMPLICATIONS}

Robertson (2010) points out that equitable access to higher education has increased the number of students from diverse backgrounds. The changing workforce worldwide has 
escalated this trend. Many universities across the globe have expanded from educating a small elite of $4-6 \%$ of their populations to educating up to $50 \%$ or more of their populations (Robertson, 2010). Educational institutions today face increasing pressure to adapt their practices to changes in their student populations.

The purpose of this study was to explore immigrant students' challenges and experiences relating to different types of support services available to them at three Icelandic universities. An additional aim was to reveal university staff perspectives regarding the support services they provide. The findings show considerable similarities between student and staff responses concerning formal and informal support. The findings also indicate that there are various types of formal support at the universities, such as, academic counselling, individual and group counselling, peer counselling, writing centres, student housing, orientations for new students at the beginning of the school year, job counselling, and courses for students of immigrant backgrounds. Despite all these types of formal support, the study also revealed that immigrant students face different challenges as university students. Universities need to adopt new strategies and understand immigrant students' distinct social contexts to serve students from various racial, linguistic, ethnic, and economic backgrounds. Previous research shows that the lack of culturally appropriate strategies can potentially lead to unfavourable learning outcomes and negatively impact students' integration into the learning environments (Engstrom \& Tinto, 2008; Sinacore \& Lerner 2013).

The findings also revealed that the majority of teachers understand the growing diversity of students in Icelandic universities and are open to discussing and resolving issues that appear during the educational process. This is in line with critical multicultural theory that emphasises the importance of caring about students' academic progress and their diverse experiences of the educational process (Parekh, 2006). Acknowledging and valuing students can create a positive learning environment where every student feels valued and has equal educational opportunities regardless of nationality, race or any other status (Lindsey et al., 2005; Parekh, 2006).

When it comes to language and linguistic support, the findings revealed that the staff members were able to provide services both in Icelandic and English. They showed understanding of the challenges caused by the language barriers that immigrant students experience. This corresponds to findings from previous research and theory in the field (Franke, 2015; Ragnarsdóttir \& Blöndal, 2007; Sinacore \& Lerner, 2013). The participants valued writing centres that offer group and individual tutoring sessions on written assignments both in Icelandic and English. Further discussion on languagerelated issues among the participants of this study can be found in other articles from the same research project (see Benediktsson, Wozniczka, Jónsdóttir, \& Ragnarsdóttir, 2018; Benediktsson, Wozniczka, Tran, \& Ragnarsdóttir, 2019).

The students participating in this research agreed that there are a number of strategies aimed at supporting the various needs of immigrant students. Access to such support, however, appeared to differ among the students. For instance, expert-oriented support tends to be highly organized. Furthermore, different studies and the theoretical background highlight the importance of appropriate educational support as this has a positive effect on the students' sense of belonging in the learning environment. It motivates 
them and provides better opportunities for further development (Engstrom \& Tinto, 2008; Freeman, Anderman, \& Jensen, 2007). Yet, this study revealed that there is no clear framework for formal support. Moreover, formal support could be improved in a few areas, such as better access to information on university websites and programmes aimed at facilitating friendships with Icelanders outside university.

When it comes to academic staff members, such as teachers, the students' experiences tend to be positive. Some of the students referred to the academic staff's unique ways of seeing and responding to their diverse backgrounds. Previous studies in the field highlight the importance of creating a positive atmosphere of trust in the classroom and emphasise the importance of constructive dialogue between teachers and students (Boesch, 2014; Ragnarsdóttir \& Blöndal, 2014; Swaminathan \& Alfred, 2014). On the other hand, formal support, according to university staff members, adapts slowly to student needs and that is why some students prefer informal support. The example of the mentor programme demonstrates this tendency. Originally designed for exchange students, the mentor programme developed into a mixed form of assistance, combining formal and informal peer support. This mixed response on university support indicates the importance of universities committing to updating their policies to make equity and diversity central to supporting all students.

The study participants revealed that they usually rely on informal assistance from peers and families and usually ask for formal support when the issues become critical and cannot be solved without professional help. This in line with the notion of networking. The immigrant students rely on the auto-resources when there is a lack of relevant resources inside the universities. The importance of networking has been previously emphasised since it has a strong positive impact on students' academic performance and contributes to their well-being (Dennis et al., 2005; Inkpen \& Tsang, 2005; Mead et al., 2001).

Students stated that they could easily access information and support from peers and family in a relatively straightforward manner. However, this proved to be problematic for those students who were not actively seeking formal support and had less access to peer and family support. One participant interview showed how family situations can have a crucial impact on a person's decision regarding university studies. Being a family caretaker could become the first priority over academic study.

The increased diversity of cultures, languages, and races of immigrant students in our educational institutions today challenges educators and calls upon them to provide their students with varying degrees of formal and informal support inside universities. This could include giving immigrant students extra time during exams and providing information in different languages in all faculties, increasing opportunities for immigrant students to work with Icelandic students and providing extra support for writing in Icelandic. Providing support to immigrant students whose educational experiences, languages and cultures differ from that of other students is a step towards equality for all students in higher education. 


\section{REFERENCES}

Arredondo, P., Toporek, R., Brown, S. P., Kones, J., Locke, D. C., Sanchez, J., \& Stadler, H. (1996). Operationalization of the multicultural counseling competencies. Journal of Multicultural Counseling and Development, 24(1), 42-78. https://doi. org/10.1002/j.2161-1912.1996.tb00288.x

Banks, J. A. (2016). Multicultural education: Characteristics and goals. In J. A. Banks, \& C. A. M. Banks (Eds.), Multicultural education: Issues and perspectives (9th ed., pp. 2-23). Hoboken: Wiley.

Benediktsson, A. I., Wozniczka, A. K., Jónsdóttir, K. L. S., \& Ragnarsdóttir, H. (2018). Kennsla og stuðningur í íslenskum háskólum: Reynsla innflytjenda [Teaching and support in Icelandic Universities: Immigrant students' experiences]. Netla - Veftímarit um uppeldi og menntun. https://doi.org/10.24270/netla.2018.5

Benediktsson, A. I., Wozniczka, A. K., Tran, A. D. K., \& Ragnarsdóttir, H. (2019). Immigrant students' experiences of higher education in Iceland: Why does culturally responsive teaching matter? Nordic Journal of Comparative and International Education (NJCIE), 3(2), 37-54. https://doi.org/10.7577/njcie.2850

Boesch, B. (2014). The importance of the professor in college classroom climate for immigrant students. College Quarterly, 17(4). Retrieved from https://eric.ed.gov /?id=EJ1058110

Bossu, C., Brown, N., Warren, V. (2018). Professional and support staff in higher education. In C. Bossu, \& N. Brown (Eds.), Professional and support staff in higher education (pp. 1-8). Singapore: Springer

Braun, V., \& Clarke, V. (2013). Successful qualitative research: A practical guide for beginners. London: SAGE.

Brinkmann, S., \& Kvale, S. (2015). InterViews: Learning the craft of qualitative research interviewing (3rd ed.). Los Angeles: SAGE.

Creswell, J. W. (2008). Educational research: Planning, conducting, and evaluating quantitative and qualitative research (3rd ed.). Upper Saddle River: Pearson.

Crisp, G., \& Cruz, I. (2009). Mentoring college students: A critical review of the literature between 1990 and 2007. Research in Higher Education, 50(6), 525-545. https://doi. org/10.1007/s11162-009-9130-2

Dennis, J. M., Phinney, J. S., \& Chuateco, L. I. (2005). The role of motivation, parental support, and peer support in the academic success of ethnic minority first-generation college students. Journal of College Student Development, 46(3), 223-236. https://doi. org/10.1353/csd.2005.0023

Engle, J., \& Tinto, V. (2008). Moving beyond access: College for low-income, first-generation students. Washington: Pell Institute for the Study of Opportunity in Higher Education.

Engstrom, C., \& Tinto, V. (2008). Access without support is not opportunity. Change, 40(1), 46-50. https://doi.org/10.3200/CHNG.40.1.46-50

European Commission. (2015). The European higher education area in 2015: Bologna process implementation report. Luxembourg: Publications Office of the European Union.

Flick, U. (2009). An introduction to qualitative research (4th ed.). London: SAGE. 
Franke, R. (2015). Why the status quo isn't good enough - examining student success for diverse populations in the United States. In R. M. O. Pritchard, M. Klumpp, \& U. Teichler (Eds.), Diversity and excellence in higher education: Can the challenges be reconciled? (pp. 109-131). Rotterdam: Sense Publishers.

Freeman, T. M., Anderman, L. H., \& Jensen, J. M. (2007). Sense of belonging in college freshmen at the classroom and campus levels. The Journal of Experimental Education, 75(3), 203-220. https://doi.org/10.3200/JEXE.75.3.203-220

Giroux, H. A. (1993). The politics of insurgent multiculturalism in the era of the Los Angeles uprising. The Journal of the Midwest Modern Language Association, 26(1), 12-30. https://doi.org/10.2307/1315443

Gloria, A. M., \& Rodriguez, E. R. (2000). Counseling Latino university students: Psychosociocultural issues for consideration. Journal of Counseling \& Development, 78(2), 145-154. https://doi.org/10.1002/j.1556-6676.2000.tb02572.x

Gray, M. J., Rolph, E. S., \& Melamid, E. (1996). Immigration and higher education: Institutional responses to changing demographics. Santa Monica: RAND.

Hertzberg, F. (2017). Swedish career guidance counsellors' recognition of newly arrived migrant students' knowledge and educational strategies. Nordisk tidsskrift í veiledningspedagogikk, 2(1), 45-61. https://doi.org/10.15845/ntvp.v2i1.1220

Inkpen, A. C., \& Tsang, E. W. K. (2005). Social capital, networks, and knowledge transfer. Academy of Management Review, 30(1), 146-165. https://doi.org/10.5465/ amr.2005.15281445

Jehangir, R. R. (2010). Higher education and first-generation students: Cultivating community, voice, and place for the new majority. New York: Palgrave Macmillan.

Lichtman, M. (2013). Qualitative research in education (3rd ed.). Thousand Oaks: SAGE.

Lindsey, R. B., Roberts, L. M., \& Campbell Jones, F. (2005) The culturally proficient school: An implementation guide for school leaders. Thousand Oaks: Corwin.

Maunonen-Eskelinen, I., Kaikkonen, L., \& Clayton, P. (2005). Counselling immigrant adults at an educational institution. In M. Launikari, \& S. Puukari (Eds.), Multicultural guidance and counselling: Theoretical foundations and best practices in Europe (pp. 265287). Jyväskylä: CIMO.

Mead, S., Hilton, D., \& Curtis, L., (2001). Peer support: A theoretical perspective. Psychiatric Rehabilitation Journal, 25(2), 134-141, https://doi.org/10.1037/h0095032

Owens, J., \& Lynch, S. M. (2012). Black and Hispanic immigrants' resilience against negative-ability racial stereotypes at selective colleges and universities in the United States. Sociology of Education, 85(4), 303-325. https://doi.org/10.1177/0038040711435856

Parekh, B. C. (2006). Rethinking multiculturalism: Cultural diversity and political theory (2nd ed.). New York: Palgrave Macmillan.

Paulus, T. M., \& Lester, J. N. (2016). ATLAS.ti for conversation and discourse analysis studies. International Journal of Social Research Methodology, 19(4), 405-428. https:// doi.org/10.1080/13645579.2015.1021949

Ragnarsdóttir, H., \& Blöndal, H. (2007). Háskólastigið í ljósi hnattvæđingar: Rannsókn á stöđu og reynslu erlendra nemenda við Kennaraháskóla Íslands [University education in light of globalisation: Research on the position and experiences of immigrant students at the Iceland University of Education]. Uppeldi og menntun, 16(2), 161-182. 
Ragnarsdóttir, H., \& Blöndal, H. (2014). Fjölmenningarlegt námssamfélag: Reynsla nemenda af alpjóđlegu námi í menntunarfræđi við Háskóla Íslands [Multicultural learning community: The experiences of students in the International Studies in Education programme at the University of Iceland]. Uppeldi og menntun, 23(1), 27-45.

Reykjavík University. (n.d.). Services. Retrieved from https://en.ru.is/services/

Robertson, S. L. (2010). Challenges facing universities in a globalising world. Bristol: Centre for Globalisation, Education \& Societies. Retrieved from https://susanleerobertson.files.wordpress.com/2012/07/2010-robertson-challenges.pdf

Sinacore, A. L., \& Lerner, S. (2013). The cultural and educational transitioning of first generation immigrant undergraduate students in Quebec, Canada. International Journal for Educational and Vocational Guidance, 13(1), 67-85. https://doi.org/10.1007/ s10775-013-9238-y

Snowman, J, \& Biehler, R. (2006). Psychology applied to teaching (11th ed.). New York: Houghton Mifflin.

Statistics Iceland. (2017). Immigrants and persons with foreign origin 2017. Retrieved from https://www.statice.is/publications/news-archive/population/immigrants-and-persons-with-foreign-background-2017/

Statistics Iceland. (2018a). Fjöldi nýnema á háskólastigi hefur tvöfaldast á tuttugu árum [Number of new university students doubled during past twenty years]. Retrieved from https://hagstofa.is/utgafur/frettasafn/menntun/nynemar-i-haskolum-2010-2017/

Statistics Iceland. (2018b). Immigrants and persons with foreign background 2018. Retrieved from https://statice.is/publications/news-archive/inhabitants/population-by-origin-2018/

Statistics Iceland. (2018c). More new entrants in vocational education at the upper secondary level. Retrieved from https://www.statice.is/publications/news-archive/ education/new-entrants-at-the-upper-secondary-level-2017/

Statistics Iceland. (2018d). New entrants at the tertiary level in 2017 twice as many as in 1997. Retrieved from https://www.statice.is/publications/news-archive/education/ new-entrants-at-the-tertiary-level-2010-2017/

Statistics Iceland. (2018e). Statistics on children in Iceland. Retrieved from https://www. statice.is/publications/news-archive/children/statistics-on-children/

Swaminathan, R., \& Alfred, M. V. (2001). Strangers in the mirror: Immigrant students in the higher education classroom. Adult Learning, 13(1), 29-32. https://doi. org/10.1177/104515950101200408

University of Akureyri. (n.d.). Library. Retrieved from https://www.unak.is/english/ student/services-support/library

University of Iceland. (n.d.-a). Libraries and bookstores. Retrieved from https://english. hi.is/university/libraries_and_bookstores

University of Iceland (n.d.-b). Mentorar [Mentors]. Retrieved from https://www.hi.is/ nam/mentorar

Wilson, W. L., \& Arendale, D. R. (2011). Peer educators in learning assistance programs: Best practices for new programs. New Directions for Student Services, (133), 41-53. https://doi.org/10.1002/ss.383

Wozniczka, A. K., \& Ragnarsdóttir, H. (2016). Lög, stefna og úrræđi í málefnum háskólanema af erlendum uppruna í premur háskólum á Íslandi [Legislation, policies and 
resources in matters relating to students of foreign origin in three universities in Iceland]. Netla - Veftímarit um uppeldi og menntun, Sérrit 2016-Menntakvika. Retrieved from http://netla.hi.is/serrit/2016/menntun_mannvit_og_margbreytileiki_greinar_fra_ menntakviku/003.pdf

The article was received 1st October 2019 and was accepted 20th May 2020

\section{ABOUT THE AUTHORS}

Susan Rafik Hama (srh2@hi.is) is a Ph.D. candidate at the School of Education, University of Iceland. She completed a diploma in pedagogy from the Institute of Education in Suleimany in Iraqi Kurdistan in 1993, a B.A. degree in English language and literature from Salahaddin University in 1997, a B.A. degree in Icelandic as a second language in 2011, a teaching certificate in 2008 and an M.Ed. degree in adult education and human resources development from the University of Iceland in 2012. Her research interests are in the education of immigrants and refugees, inclusive and multicultural education, pedagogy vs andragogy and lifelong learning.

Artëm Ingmar Benediktsson (artem@hi.is) is a Ph.D. candidate at the School of Education, University of Iceland. He completed a B.S. degree in geology from the People's Friendship University of Russia in 2008, a B.A. degree in Danish from the University of Iceland in 2013 and an M.A. degree in Nordic studies from the University of Iceland in 2015. Artëm embarked on his Ph.D. in 2016. His research focuses on immigrant students' experiences of learning environments and teaching methods used in Icelandic universities.

Borkur Hansen (borkur@hi.is) is a professor at the School of Education, University of Iceland. He completed a B.A. degree in education and psychology from the University of Iceland in 1982, an M.Ed. degree from the University of Alberta in 1984 and a Ph.D. degree in 1987. His major research interests are in the areas of leadership, school management, school development and educational governance.

Kriselle Lou Suson Jonsdottir (kls5@hi.is) was a research assistant in this project. She completed B.A. degree in international studies in education from the University of Iceland in 2013 and a master's degree in education at the University of Iceland in 2017. Her research focuses on literacy skills and the linguistic diversity of children. She currently works as a specialist at Reykjavik City's Office of the Department of Education and Youth.

Hanna Ragnarsdottir (hannar@hi.is) is a professor at the School of Education, University of Iceland. She completed a B.A. degree in anthropology and history from the University of Iceland in 1984, an M.Sc. degree in anthropology from the London School of Economics and Political Science in 1986, and a Dr.philos. in education from the University of Oslo in 2007. Her research has mainly focused on immigrants and refugees (children, adults, and families) in Icelandic society and schools, multicultural education, and school reform. 